\title{
Pencitraan dalam Buku Antologi Puisi Mengagumi dalam Diam Siswa SMPN 43 Bandung
}

\author{
Moh.Nurman Bagus Satrio ${ }^{(1)}$, Agus Hermawan ${ }^{(2)}$ \\ ${ }^{1}$ Program Studi Kimia Universitas PGRI Banyuwangi, Indonesia \\ ${ }^{2}$ Program Studi Pendidikan Bahasa Indonesia \\ Email: ${ }^{1}$ E-mail: riobanyuwangi22@gmail.com, \\ ²E-mail: agushermawan8992@gmail.com,
}

\begin{abstract}
Abstrak: Sastra bagian dari ciptaan manusia yang melibatkan aspek nilai rasa /ide yang terdapat dalam benaknya dengan memanfaatkan bahasa sebagai alatnya. Di dalan sastra tidak hanya terdapat tulisan yang bersifat menghibur, tetapi ternyata terdapat makna yang sangat mendalam dan bisa menambah pengalaman kehidupan manusia. Pengetahuan pada karya sastra tidak hanya di pahami dari unsur intrinsik tetapi juga di pahami dari segi ekstrinsik. Semua yang terjadi pada karya sastra bias juga terjadi dalam dunia nyata. Begitu pula pencitraan puisi dalam menikmatinya ada beberapa indra perasa
\end{abstract}

\begin{tabular}{l}
\hline Tersedia Online di \\
\hline http://journal.unublitar.ac.id/pendidik \\
\hline an/index.php/Riset_Konseptual \\
\hline Sejarah Artikel \\
\hline Diterima pada : 20-04-2021 \\
Disetuji pada : 28-04-2021 \\
Dipublikasikan pada : 30-04-2021 \\
\hline Kata Kunci: \\
\hline Karya sastra, Stilistika, Citraan. \\
DOI: \\
http://doi.org/10.28926/riset_konseptual.v5i \\
2.356
\end{tabular}
yang dipakai dalam buku antologi puisi” Mengagumi dalam Diam “ Puisi karya siswa SMP 43. Peneliti menganalisis pencitraan didalam puisi tersebut untuk lebih memahami dan menikmati puisi.

\section{PENDAHULUAN}

Sastra bagian dari ciptaan manusia yang melibatkan aspek nilai rasa dan ide yang terdapat dalam benaknya dengan memanfaatkan bahasa sebagai alatnya Tarigan (1995:3). Di dalan sastra tidak hanya terdapat tulisan yang bersifat menghibur, tetapi ternyata terdapat makna yang sangat mendalam dan bisa menambah pengalaman kehidupan manusia. Hakikatnya, karya sastra merupakan bagian yang sangat penting yang yang memberikan wajah berbeda dang mengandung unsur-unsur keindahan tersendiri pada kehidupan manusia dalam menciptakan kebudayaan. Hal ini sebagaimana dinyatakan Semi (1984: 54) bahwa sastra merupakan bagian daripada kebudayaan. Puisi bagian dari karya sastra dapat mengungkapkan isi hati dan perasaan masalah manusia dalam hidupnya dan kehidupannya bisa bermanfaat bagi pembaca.

Sedangkan Rahmad Djoko Pradopo (2010:7) menyimpulkan dari beberapa pendapat tentang definisi puisi. "Puisi itu mengekpresikan pemikiran yang membangkitkan perasaan, yang merangsang imajinasi panca indra pada susunan yang berirama, menarik dan memberi kesan. Puisi itu merupakan rekaman dan intreprestasi pengalaman manusia yang penting, di ubah pada wujud yang paling berkesan." Perbedaan puisi dengan karya sastra lain (prosa) sifatnya hanya bersederajat saja kadar kepadatannya. Dengan pengetahuan pembaca puisi menjadi lebih bermakna dalam nilai rasa dan pencitraannya.

Dalam dunia sekarang ini nilai-nilai sastra di masyrakat kurang dipahami betul dan mulai memudar. Karena terjadi perubahan teknologi yang cukup besar dan berpengaruh pada masyrakat. Salah satu cara untuk menikmati sastra melalui pencitraan indra dalam sebuah puisi disitu nanti akan mendapatkan makna yang 
sangat mendalam. Dalam buku antologi puisi "Mengagumi dalam Diam" puisi karya siswa SMP 43 Bandung peneliti ingin menyampaikan 5 Citraan yang terdapat dalam puisi yaitu : (a) pencitraan penglihatan, (b) pencitraan pendengaran, (c) pencitraan perabaan, (d) pencitraan pendengaran, (e) pencitraan gerak. Bait buku antologi puisi "Mengagumi dalam Diam" karya siswa SMP 43 Bandung. Melihat permasalahan tersebut, peneliti ingin lebih luas mengajak pembaca memamahi citraan yang ditulis oleh anak SMP agar kita bisa menikmati karya puisinya. Mendapatkan Bahasa-bahasa yang bersifat positif terhadap masyrakat pembaca. Mengacu padahal tersebut membuat hasil karya buku antologi puisi "Mengagumi dalam Diam" puisi karya siswa SMP 43 Bandung menarik untuk diteliti tentang sumbangsihnya sudah ada Citraan dalam karya puisinya yang bisa kita lihat dari hasi penelitiannya nanti. Selain itu gaya citraan atau gaya stilistikanya mampu menimbulkan kesan yang menarik.

\section{METODE}

Penelitian bagian kegiatan ilmiah yang memerlukan metode untuk penyelesain masalah penelitian secara efektif dan efisien. Untuk itu, metode cara yang sistematis dalam pelaksanaan suatu penelitian untuk mencapai penelitian. Menurut pendapat Ratna (2004:53) pendekatan adalah cara-cara menghampiri objek, yaitu karya sastra. Dengan adanya pendekatan dalam suatu penelitian tersebut kearah yang lebih tepat sesuai dengan tujuan penelitian. Sependapat dengan itu Satori (2010:25) Pendekatan kualitatif yang mengungkap situasi social tertentu dengan mendeskripsikan kenyataan secara benar, dibentuk oleh kata-kata berdasarkan teknik pengumpulan data dan analisis yang relevan

Berdasarkan uraian diatas maka pendekatan yang digunakan dalam penelitian ini adalah pendekatan kualitatif. Hal ini didasarkan atas dua pertimbangan anatara lain penelitian ini datanya berupa kata-kata atau data penelitian kualitatif. Kedua tujuan penelitian ini merupakan citraan puisi buku antologi puisi "Mengagumi Dalam Diam" karya siswa SMP 43 Bandung.

Penelitian sastra ini menggunakan metode deskriptif kualitatif yaitu metode penelitian yang menggunakan objek bahasa atau kata-kata. Penelitian kualitatif mendiskripsikan makna data yang dapat ditangkap dengan menunjukkan bukti buktinya. Penelitian ini bertujuan mengkaji Pencitraan Indera yang terdapat dalam buku antologi puisi “ Mengagumi dalam diam puisi karya siswa SMP 43 Bandung. Berdasarkan wujud dan sifat data penelitian ini sama dengan sifat penelitian deskriptif kualitatif seperti yang telah dipaparkan.

Jenis penelitian deskriptif dapat diartikan sebagai salah satu jenis penelitian yang berusaha memahami unsur-unsur intrinsic dalam karya sastra serta melihat hubungan dan peranan antar unsur-unsur tersebut. Aminuddin $(2010 ; 164)$ mengatakan bahwa : "penelitian deskriptif adalah analisis dalam mengapresiasi unsur -unsur intrinsic dalam puisi dan mengidentifikasi peranan setiap unsur intrinsic dan ekstrinsik serta berusaha memahami bagaimana hubungan antara yang satu dan yang lainnya.

Tahapan penelitian ialah suatu langkah-langkah yang dilakukan untuk melaksanakan suatu penelitian. Tahapan atau langkah -langkah penelitian wajib mengikuti prosedur secara sistematis, berencana dan mengikuti konsep ilmiah. Hal tersebut sesuai dengan pendapat arikunto (2006:20) bahwa persyaratan penting dalam mengadakan kegiatan penelitian adalah sistematis, berencana dan mengikuti konsep ilmiah.

Prosedur penelitian dibagi menjadi 3 tahap (1) tahap persiapan, (2) tahap Pelaksanaan, (3) tahap pelaporan (arikunto, 2006;16)

Sumber data sangat diperlukan pada sebuah penelitian. Menurut Siswantoro (2010:70) data adalah sumber informasi yang akan diseleksi sebagai sumber analisis. Dari definisi tersebut. Data penelitian berarti semua hal yang dimiliki dapat diolah dan dianalisis. Data penelitian dapat diperhitungkan dan fakta diperlukan membantu 
penelitian. Data penelitian ini adalah kata-kata dalam beberapa puisi dalam buku buku antologi puisi " Mengagumi dalam diam puisi karya siswa SMP 43 Bandung.

Prosedur pengumpulan data adalah cara untuk mengambil data secara objektif, jelas dan benar. Pengumpulan data penelitian ini menggunakan teknik simak dan teknik catat. Teknik simak diperlakukan untuk memahami teks atau naskah (sudaryanto, 1988;2). Adapaun teknik catat merupakan cara yang dilakukan peneliti untuk mencata secara langsung data pada naskah. adalah:

Adapun langkah-langkah untuk mengumpulkan data dalam penelitian ini

1. Membaca teks puisi secara menyeluruh

2. Membaca ulang teks puisi untuk memastikan calon data

3. Mencatat calon data kedalam table data sesuai dengan aspek yang diteliti.

4. Mengklasifikasikan data sesuai indicator atau aspek yang diteliti.

Analisis data adalah upaya dilakukan peneliti dengan cara mengorganisasikan data, memilah-milah data menjadi satuan yang dapat dikelola dan memutuskan apa yang akan ditulis (Moelong,2005; 248). Teknik analisis data yang digunakan dalam penelitian ini adalah teknik konten analisis atau kajian isi.

Analisis data adalah upaya yang dilakukan dengan jalan bekerja dengan data, mengorganisasikan data, memilah-milahnya menjadi satuan yang dapat dikelola, mensistensiskannya, mencari dan menemukan pola, menemukan apa yang penting dan apa yang dipelajari, dan memutuskan apa yang dapat diceritakan kepada o-rang lain. Hal ini sesuai dengan pendapat Bogdan dan Biklen (Moelong, 2005:248). Adapun langkah-langkah analisis data penelitian ini sebagai berikut:

1. Membaca secara intensif dan berulang-ulang kajian teori pada penelitian ini serta semua literature yang mendukung objek penelitian

2. Membaca ulang data yang telah dikumpulkan.

3. Mendeskripsikan data berdasrkan teori secara urut sesuai dengan rumusan masalah

4. Mencatat simpulan hasil penelitian.

5. Pengabsahan data.

\section{HASIL dan PEMBAHASAN}

\section{Deskripsi Pencitraan puisi dalam Buku antologi puisi "Mengagumi dalam diam" karya siswa SMP 43 Bandung.}

Citraan juga merupakan salah satu sara kepuitisan dipakai penyair dalam memperkuat gambaran dan pikiran dalam perasaan pembaca. Sarana ini sangat berkaitan erat dengan pengalaman penyair yang dituangkan dalam puisi. Oleh karena itu citraan tidak membuat kesan, melainkan melibatkan pembaca untuk terlibat dalam kreasi puisi. Hal ini dapat dilakukan dengan dua cara yaitu, melalui deskripsi dan pelambangan (metafora).

Pembahasan pencitraan puisi, tidak lepas dari pembicaraan (a) pencitraan penglihatan, (b) pencitraan pendengaran, (c) pencitraan perabaan, (d) pencitraan pendengaran, (e) pencitraan gerak. Bait buku antologi puisi "Mengagumi Dalam Diam" karya siswa SMP 43 Bandung

\section{A. pencitraan Penglihatan}

1. Citraan Penglihatan ( visual imagery)

Citraan penglihatan adalah citraan yang terkait dengan pengkongkretan objek yang dapat dilihat oleh mata, objek yang dapat dilihat secara visual. Jadi, objek visual adalah objek yang tampak seperti meja, kursi, jendela, pintu, dan lain-lain. 
Berikut hasil data Citraan Penglihatan

\title{
BULLYING
}

\section{RISKA.M.P/9-6}

SMP NEGERI 43 BANDUNG

Disertai buku dan hand phone

Sendirian aku duduk dikursi pojok

ruangan

Hanya menatap layar handphone

Dan memperhatikan mereka....CP/001

\section{Rosa / IX- 7}

\section{SMPN 43 Bandung}

Kalau aku dalam benteng

Yang sangat kokoh

Yang disebut FANGRIL....CP/002

\section{KEHENINGAN MALAM}

\section{ALYA NAZHIITAH/9-7}

\section{SMP NEGERI 43 BANDUNG}

Lorong lorong di kegelapan lorong -lorong di kegelapan

Suara bisikan dan tertawaan seorang perempuan

Bagaimana kau bisa keluar dari sini....CP/003

Pada data diatas CP/001, CP/002 dan CP/003 yang bergaris bawah dapat dideskripsikan gambaran Citraan penglihatan.

\section{Citraan Pendengaran (auditory imagery)}

Citraan pendengaran (auditory imagery) adalah pengkongkretan objek bunyi yang ditengar oleh telinga. Citraan auditif terkait usaha pengkongkretan bunyi-bunyi tertentu, baik yang ditunjukkan lewat deskripsi verbal maupun tiruan bunyi. Sehingga seolah-olah pembaca dapat mendengarkan bunyi tersebut secara mental lewat imajinasi.

Berikut hasil data Citraan Pendengaran.

\section{IBU \\ NURANI SITI AISAH/IX-5 \\ SMPN 43 BANDUNG}

Rindu yang menghampiri

Terus saja mengerutu

Karna sang pemilik rindu

Haya diam membisu....CD/001

\section{D R}

\author{
Anisa Salsabilah Putriani Noor / IX_ 6 \\ SMP Negeri 43 Bandung \\ Begitu dalam cintaku untuknya \\ Sehingga taka da cinta yang lain \\ Aku begitu tulus padanya sampai aku takut \\ Di kecewakan...dan Riuhhhh.....CD/002
}




\section{HILANG}

\section{Tiara Ayu / IX-6}

SMP Negeri 43 Bandung

Hilang sudah

Semua kenangan manismu

Senyum indahmu dan suaramu

Disetiap pagiku.....CD/003

Pada data diatas CD/001, CD/002 dan CD/003 yang bergaris bawah dapat dideskripsikan gambaran Citraan pendengaran.

3. Citraan Perabaan (tactile imagery)

Citraan peraba (taktil termal) merupakan pelukisan perabaan secara kongkret walau hanya terjadi di rongga imajinasi pembaca. Berikut data Citraan Perabaan.

\section{SOEKARNO}

\section{ARBY ARTHA J/IX-7 \\ SMP NEGERI 43 BANDUNG}

Seorang pemuda dengan tekad merde

Pemuda yang bijaksana

Seorang yang membuat proklamasi

Pemuda yang dihormati bangsa Pemuda yang dihormati bangsa

Pahlawan dengan sejuta kata mutiara

Kaulah yang melepas tali penjajahan....CB/001

\section{KEHENINGAN MALAM}

\section{ALYA NAZHIITAH}

\section{SMP NEGERI 43 BANDUNG}

Angin dingin menyambut malam

Semua orang berdiam diri

Udara yang begitu menyesakkan...CB/002

\section{IBU}

\section{Revita / IX-7}

\section{SMPN 43 Bandung}

Perasaanmu, Keadaanmu

Ampuni aku Ibu Ampuni aku ibu....Merinding

Aku tahu, disaat aku bangun dipagi hari

Senyummmu Terpancar

Tapi...aku juga tahu disaat aku terlelap

Aku mendengar tangisan seseorang....CB/003

\section{TERIMAKASIH}

\section{Ajeng Danella / 9-6}

Aku akan jadi orang pertama yang akan

Menyayangimu tanpa henti

Kamu adalah seseorang yang membuat hari kamu

Hariku berwarna

Terima kasih atas semuanya....CB/004

Pada data diatas $\mathrm{CB} / 001, \mathrm{CB} / 002, \mathrm{CB} / 003$ dan $\mathrm{CB} / 003$ yang bergaris bawah dapat dideskripsikan gambaran Citraan Perabaan.

\section{Citraan Penciuman (olfactory)}

Citraan penciuman merupakan citraan yang menggambarkan indra penciuman seolaholah dapat mencium bau sesuatu yang dipaparkan pengarang. Citraan penciuman 
menunjukkan pada pelukisan penciuman secara kongkret walau hanya terjadi di rongga imajinasi pembaca.

Berikut data Citraan Penciuman.

\section{SESEORANG SEPERTIMU SESEORANG SEPERTIMU}

\section{Zamzam. M.J / 9-7 ZAMZAM.M.J/9-7}

SMP Negeri 43 Bandung SMP NEGERI BANDUNG

Bagai pohon,yang disambar petir

Dan bagai daun yang jatuh ke tanah

Angin, Bau wangi

Aku sungguh tidak bisa hidup sepertimu

Yang selalu bersabar...CM/001

\section{RUSAKNYA ALAMKU}

\section{NAJWA NAABILA/9-6}

\section{SMP NEGERI 43 BANDUNG}

Alam ku terluka

Seluruh semesta pun murka

Sampai kapan kita terus diam

Suaraku?

Sementara petaka mengancam

Depan mata....CM/002

Pada data diatas $\mathrm{CM} / 001$, dan $\mathrm{CM} / 002$ yang bergaris bawah dapat dideskripsikan gambaran Citraan penglihatan.

\section{Citraan Gerak (kinaesthetic imagery)}

Citraan gerak (kineistetik) adalah citraan yang terkait dengan pengkongkretan objek gerak yang dapat dilihat oleh mata. Hal ini mirip dengan citraan visual yang juga terkait dengan penglihatan. Namun, dalam citraan gerak objek yang ditunjukkan untuk dilihat adalah suatu aktivitas, gerak motoric, bukan objek diam. Lewat penggunaan kata-kata yang mengarah pada suatu aktivitas. Lewat kekuatan imajinasinya pembaca (seolaholah) dapat melihat aktivitas yang dilakukan.

Berikut data Citraan gerak.

\section{RUSAKNYA ALAMKU}

NAJWA NAABILA/9-6

SMP NEGERI 43 BANDUNG

Suara mesin menggetarkan hutan

Pohon-pohon di babat tanpa ampun

Sampai akhirnya.....

Seluruh pohon tumbang ...CG/001

\section{ESEORANG SEPERTIMU}

\section{ZAMZAM.M.J/9-7}

\section{SMP NEGERI BANDUNG}

Bagai pohon yang disambar petir

Dan bagai daun jatuh kedalam tanah

Angin

Aku sungguh tidak bisa hidup sepertimu

Yang selalu bersabar

Dan selalu menunggu

Kasihan sekali hidupmu.....CG/002 


\section{RASA SYUKUR RASA SYUKUR}

\section{Saadatun Nisaa / 9-6 SAADATUN NISSA/ 9-6}

Lihat rembulan yang selalu memberi cahaya

Malam

Tak Pernah mengeluh dari kelelahan

Lihat mentari dari timur kebarat

Memberi sinar terang

Tak mengeluh mengibas ngibas tubuhku

Kegerahan

Rasakan udara yang memberi hidup

Kepengapan nafas...CG/003

Pada data diatas CG/001, CG/002 dan CG/003 yang bergaris bawah dapat dideskripsikan gambaran Citraan penglihatan.

\section{KESIMPULAN}

Karya satra merupakan suatu hasil karya yang di dalamnya memiliki nilai seni atau keindahan, terdapat pembayangan atau pelukisan kehidupan dan pikiran imajinatif yang dituangkan kedalam bentuk atau struktur gagasan yang kemudian dikembangkan ke dalam bentuk lisan maupun tulisan. Sastra tidak hanya berfungsi sebagai hiburan saja, tetapi memiliki sejumlah manfaat. Karena di dalam karya sastra terdapat sejumlah fikiran yang dapat direnungkan oleh penikmat sastra.

Salah satu karya sastra adalah puisi. Puisi merupakan penggambaran pengalaman pengarang. Berdasarkan hasil penelitian buku antologi puisi "Mengagumi Dalam Diam" karya siswa SMP 43 Bandung, terdapat 5 Pembahasan Pencitraan Puisi, tidak lepas dari pembicaraan (a) pencitraan Penglihatan, (b) pencitraan Pendengaran, (c) pencitraan Perabaan, (d) pencitraan Pendengaran, (e) pencitraan gerak , Bait puisi buku antologi puisi "Mengagumi Dalam Diam" karya siswa SMP 43 Bandung.

\section{DAFTAR RUJUKAN}

Aminuddin. 1990. Pengantar Apresiasi sastra. Malang: Sinar Baru Bandung.

Aminuddin. 2010. Pengantar apresiasi karya sastra. Bandung: sinar baru: Algensindo Bandung.

Arikunto, Suharsimi.2006. Prosedur Penelitian"Suatu Pendekatan Praktik". Jakarta: Rineka Cipta.

Badrun, Ahmad. 1983. Pengantar Ilmu Sastra. Surabaya: Usaha Nasional.

Budianta, dkk. 2001. Membaca Sastra. Depok: Indonesia Terb.

Endraswara, Suwardi. 2003. Metodologi Penelitian Sastra. Yogyakarta: Nusa Indah.

Esten, Mursal. 2000. Kesusastraan pengertian Teori dan Sejarah. Bandung: Angkasa.

Fananie, Zainuddin. 2002. Telaah Sastra. Surakarta: Muhammadiyah University.

Mahsun. 2007. Metode Penelitian Bahasa. Jakarta: Raja Grafindo.

Mulyana, Deddy. 2006. Metodologi Penelitian Kualitatif. Bandung: PT: Remaja Rosdakarya.

Moleong, Lexy J.2005. Metode Penelitian Kualitatif. Bandung: Remaja Rosdakarya.

Nurgiyantoro, Burhan. 1998. Teori Pengkajian Fiksi. Yogyakarta: Gajah Mada University Press.

Nurgiyantoro, Burhan. 2010. Teori Pengkajian Fiksi. Yogyakarta: Gajah Mada University Press.

Ratna, Nyoman Kutha. 2010. Teori, Metode, dan Teknik Penelitian Sastra. Yogyakarta: Pustaka Pelajar.

Semi, Atar. 1990. Metode Penelitian Sastra. Bandung: Angkasa.

Teew, A. 1983. Membaca dan Menilai Sastra. Jakarta: PT. Gramedia.

Teew, A. 2003. Membaca dan Menilai Sastra. Jakarta: PT. Gramedia.

Buku Antologi Puisi “Mengagumi Dalam Diam" Siswa SMPN 43 Bandung 